\title{
Urban tourism destinations in South Africa: Divergent trajectories 2001-2012
}

\author{
Christian M. Rogerson \\ Jayne M. Rogerson
}

Christian M. Rogerson, University of Johannesburg, Faculty of Management, School of Tourism \& Hospitality, South Africa (crogerson@uj.ac.za)

Jayne M. Rogerson, University of Johannesburg, Faculty of Science, School of Geography, Environmental Management \& Energy Studies, South Africa (jayner@uj.ac.za)

\begin{abstract}
Cities are growing tourism destinations in both developed and developing countries. For policymakers in many cities the promotion of tourism is a vital issue. The phenomenon of urban tourism has emerged as a significant research topic in tourism and urban studies. The South African experience has been one of the most well documented cases in urban tourism in the developing world. Most existing research is focussed on supply-side issues of the establishment of new tourism products in cities or of the impacts of growing urban tourism. This article examines urban tourism from a demand-side perspective and interrogates the performance of South Africa's eight metropolitan areas as tourism destinations over the period 2001-2012.The analysis reveals that the metropolitan areas as a group are expanding in significance as tourism destinations. Divergent pathways or trajectories of development are apparent in terms of unpacking the performance of the eight different areas.
\end{abstract}

Keywords: urban tourism, South Africa, purpose of travel, domestic tourism, international tourism

\section{Introduction}

The stimulation of economic growth and accelerated rates of job creation have been major priorities for urban policy makers in South Africa particularly in the period since democratic transition. With the conferment of a developmental mandate upon South African local governments under the 1996 Constitution the challenge of local economic development has come under the policy spotlight (Rogerson, 2000; Binns \& Nel, 2002; Nel \& Rogerson, 2005a; Rogerson \& Rogerson, 2010, 2012). In addressing this issue South African cities have pursued a range of different interventions in order to galvanize economic expansion, to create new employment opportunities as well as to tackle chronic problems around poverty reduction (Nel \& Rogerson, 2005a, 2005b). Interventions and support initiatives have ranged across variously cluster promotion, maximising opportunities for small enterprise development, encouraging creative industries (including film), call centres, high technology activities and energising locally competitive production activities (Rogerson, 2004, 2008a, 2010, 2011a, 2011b, 2013a; Pandy \& Rogerson, 2012, 2014; Visser, 2014). In many respects these forms of promotion around local economic development in cities are a mirror of parallel policy developments which have occurred in cities of the global North (see eg. Reid \& Smith, 2012).

For cities confronted by the challenges of embracing the service economy and information age, tourism is an alluring sector for policy-makers. It affords them an opportunity to reposition as well as to redefine their essential functions (Law, 1993). In addition, tourism has been seen by policy makers as a lever for urban regeneration and for breathing life back into the historic and often declining areas of cities (Galdini, 2007). It is recognised that several advantages accrue from successful projects of tourism-led regeneration particularly in innercity areas (Law, 1992). Arguably, of critical significance are the direct or indirect effects for 
job creation and other wider economic impacts. Another critical benefit, however, relates to the impact of tourism upon city imaging as well as physical and environmental improvements which can accompany tourism-driven urban regeneration projects (Rogerson, 1996; Galdini, 2007; Ioannides \& Timothy, 2010). Finally, the improved images of cities can have other positive impacts in respect of enhancing the overall business climate for private sector investment as well as for the attraction of creative industries and creative individuals (Richards, 2012). Overall, tourism development in cities "has become an essential tool for economic regeneration and employment creation, for place promotion, for re-imaging cities and helping to create identity in the new global systems” (Williams, 2009: 208).

In South Africa the tourism sector has been a special focus for national economic development programming particularly since 1994 and the country's re-integration into the global tourism economy. As emphasized by Rogerson \& Visser (2004) under apartheid the tourism sector was of only minor importance as international tourism was undeveloped as a consequence of international boycotts and sanctions. Although the growth of international tourism in South Africa is associated with the country's big 5 nature attractions, the country's cities are major destinations for tourism. In common with international experience, South African cities have taken up the challenge of promoting urban tourism, including for purposes of economic regeneration (Rogerson, 2002a, 2002b; Ferreira \& Visser, 2007; Rogerson, 2013b). As has been shown elsewhere a number of different policy interventions have been undertaken to strengthen the tourism product base of the country's cities (Rogerson \& Visser, 2007). Supply-side interventions have encompassed the establishment of new entertainment complexes, casino developments, heritage tourism attractions, convention centres, and aggressive competitive bidding to hosting mega-events (Rogerson \& Visser, 2007, 2011). In addition, Johannesburg has taken the lead in seeking to build the potential of township tourism and of creative tourism as well as maximising the city's attractiveness as a shopping destination, in particular for shopper/traders from neighbouring African countries (Rogerson, 2006; Rogerson \& Visser, 2006; Rogerson, 2008b; Booyens, 2010; Rogerson, 2011b, 2013b).

In an overview of scholarship dealing with South African urban settlements for the period 2000-2010 Visser (2013) identifies tourism as one of the leading 'growth poles' in urban studies research. The importance of urban tourism for South African urban research is confirmed in a further overview of contemporary urban research (Visser \& Rogerson, 2014). The expansion of research on urban tourism is acknowledged also in recent discussions of the state of the art of local and regional tourism writings (Rogerson \& Rogerson, 2011; Visser \& Hoogendoorn, 2011). Against this background the aim in this paper is to extend South African debates around urban tourism by analysing the changing patterns and performance of urban tourism within the country's eight major metropolitan areas over the period 2001-2012. The timeframe for this investigation is of particular interest as it spans a phase of considerable expansion in the national tourism economy which includes the hosting of the 2010 FIFA Soccer World Cup. The findings of this investigation are set within the context of a brief contextual review of international research and debates about urban tourism.

\section{Urban Tourism Debates}

As pointed out by Murillo et al. (2011: 4) although tourists visiting cities represent one of the earliest forms of travel "it was only during the last decades of the twentieth century that many cities became aware of its economic potential and embraced it as a key sector inside their economies". Indeed, during the past three decades one of the most common local development strategies in cities has been support for the tourism sector to be a vehicle for urban economic improvement. Across Western Europe, North America and Australia, cities which formerly were places of production have been re-structured and re-invented as places of consumption. Among others, Ismail \& Baum (2006: 213) draw attention to "a multitude of 
motivations associated with visitation in urban areas”. Law (1993: 1) considers the period of the 1980s as a watershed with a "significant shift in attitude by cities towards the tourism industry“. Key trigger factors for policy interest on tourism were global restructuring and ongoing processes of deindustrialization of cities, the imperative to introduce new growth sectors and the perception of tourism as such a growth sector. Now, according to Williams (2009: 208) "urban tourism has acquired a level of significance through its new found centrality in the processes of reinvention of cities under post-industrial, postmodern change and the related restructuring of urban economies and societies around consumption”.

In a landmark work on urban tourism which appeared in the early 1990s Law (1993: 2) forwarded that the study of tourism in large cities, or urban tourism, "has not attracted much attention in the academic literature". More recently it was stated that whilst "the importance of urban tourism is now widely recognised, it is a subject that has, until very recently, been an area of relative neglect within tourism studies” (Williams, 2009: 208). This said subsequent to the publication of Law's $(1992,1993)$ seminal studies in the 1990s there occurred a rise of interest around urban tourism issues (Galdini, 2007). By the early 2000s urban tourism was established as a distinct knowledge area within urban studies and tourism studies (Ismail \& Baum, 2006). Currently, urban tourism continues to secure considerable research attention from a number of disciplines with contributions from urban scholars, human geographers and tourism researchers (Hall \& Page, 2009; Ashworth \& Page, 2011; Spirou, 2011). In reviews of international writings on urban tourism Ashworth \& Page (2011: 2) underscore the "intellectual health" and the consolidation of "a well-established quantum of urban tourism research" and Selby (2012: 233) draws our attention to the significant contributions made by human geographers "to a functional understanding of urban tourism through focusing on the urban tourism product”.

Arguably, urban tourism scholarship is a broad field of investigation. One critical theme in urban tourism expansion is, however, the growth of the accommodation sector, most importantly of hotels. The development of the accommodation industry in general and of the hotel economy in particular is critical to understanding the rise of urban tourism. Within urban tourism therefore there exists a stream of writings on hotels and their location in cities (eg. Arbel \& Pizam, 1977; Shoval et al., 2011; Rogerson, 2012, 2014). Among a suite of broader questions that have garnered research attention are the impact of tourism upon cities; the competitiveness of urban tourism destinations; the role of urban tourism in local economic restructuring and physical revitalisation; globalisation and urban tourism; host-visitor relationships; and, the relationships between creativity and urban tourism development (Hall \& Page, 2009; Ashworth \& Page, 2011; Spirou, 2011; Richards, 2012). Other matters that have come under academic investigation are the local impacts of tourism for gentrification (Fuller \& Michel, 2014), urban tourism occurring in less affluent or peripheral 'edgy' urban districts (Smith \& Pappalepore, 2014), evaluations of urban tourism product and visitor satisfaction (Ben-Dalia et al., 2013), residents perceptions (Wang et al., 2005), the application of real estate as a policy stimulus (Xu et al., 2012), and the pro-poor impacts of urban tourism (Butler et al., 2013; Frenzel, 2013). Miller et al. (2014) focus attention on questions of sustainable urban tourism and of tourists' pro-environmental behaviours. Finally, in a useful comparative investigation of Antalya, Amsterdam and Liverpool, Ozturk \& Terhorst (2012) observe the divergent nature and trajectories of urban tourism development. The different pathways of urban tourism across various urban tourism destinations are further highlighted by Kadar's (2013) recent work on Vienna and Prague.

One consistent trend in urban tourism scholarship is a broadening in the geographical range of cities under investigation and confirmation of the globalising nature of the phenomenon of urban tourism. Nevertheless, in the important review articles by Hall \& Page (2009) and by Ashworth \& Page (2011) it is apparent that the international scholarship on 
urban tourism is geographically uneven with most writings focussed on cities in North America and Europe. As pointed out by Ismail \& Baum (2006: 214)"many of the descriptions of what constitutes urban tourism are based on the experience of developed countries". Nevertheless, during the past decade cities in Pacific Asia and especially China have attracted rising attention (Begin, 2000; Wang et al., 2005; Li \& Bihu, 2012; Xu et al. 2012; Hong, 2014). It is observed also the appearance of works which track tourism development in the Middle Eastern Gulf region especially Dubai and Abu Dhabi (Henderson, 2014). Growing attention is evident in urban tourism destinations in the developing world. Studies have appeared on Botswana (Moswete et al., 2008), India (Singh, 1992), Iran (Azizi, 2011), Malaysia (Ismail \& Baum, 2006), and most importantly South Africa where urban tourism has been a popular topic for both urban and tourism researchers over the past decade (Rogerson, 2002; Rogerson \& Visser, 2004, 2006; Ferreira \& Visser, 2007; Abrahams, 2009; Ferreira, 2011; Rogerson \& Visser, 2011; Visser, 2013). Across the developing world one of the most distinctive aspects of urban tourism scholarship relates to the controversial phenomenon of so-termed 'slum tourism' in which tourists mainly from the global North travel to poor areas of cities in the global South (Rolfes, 2010; Frenzel et al., 2012; Frenzel, 2013). South Africa, Brazil, Kenya and India are among the growing number of countries where slum tourism is an expanding phenomenon and parallel focus of research attention (Burgold \& Rolfes, 2013; Chege \& Mwisukha, 2013; Kieti \& Magio, 2013; Steinbrink, 2013; Chege \& Weweru, 2014).

\section{Urban Tourism Destinations in South Africa: Divergent Trajectories}

As indicated the topic of urban tourism in South Africa has been explored and unpacked in a series of recent studies which review in particular the establishment of different tourism products and of new niche forms of tourism (Rogerson \& Visser, 2007, 2011). Much of the existing base of works concentrates upon supply-side considerations and looks at the nature of different urban tourism products or undertakes evaluations of the impacts of this growing phenomenon. One theme that remains unexplored is the demand-side of urban tourism and of the differential growth and performance of various South African cities as tourism destinations. This gap, to a large extent, has been the result of the generally poor state of spatialised tourism data which is available from official sources such as South African Tourism. 


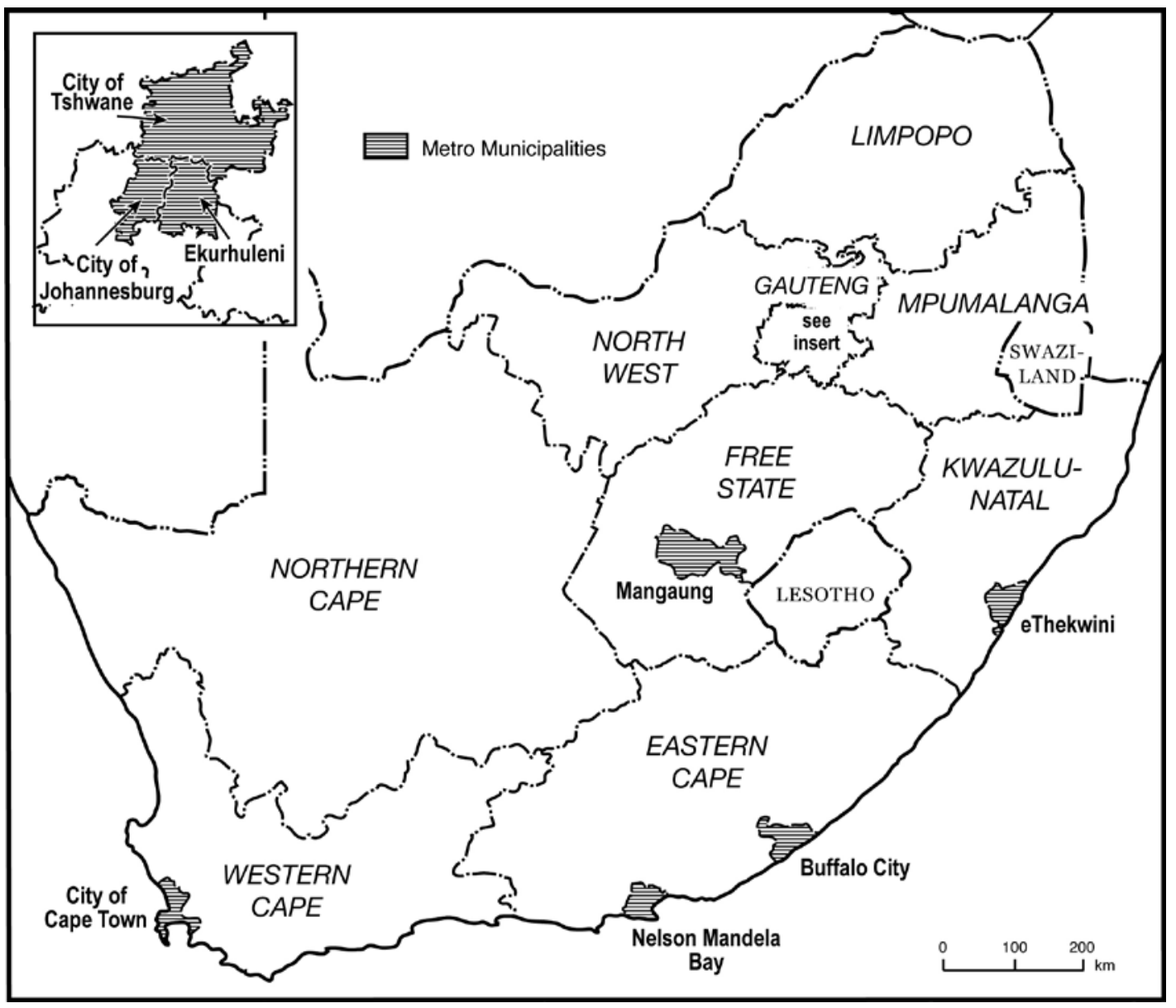

Figure 1: The Location of South Africa’s Eight Metropolitan Municipal Areas

In addressing this knowledge gap about urban tourism in South Africa, a detailed analysis is undertaken of a local level data base which has been constructed by Global Insight. This data base builds upon a range of sources including official tourism data and other local sources in order to generate estimates of trips, bednights and visitor spend for all local government areas in South Africa. More specifically this data base gives details for the period 2001 to 2012 of the tourism performance of all local authorities in the country in respect of inter alia, the number of tourism trips as differentiated by purpose of trip; number of trips and bednights by origin of tourist (domestic or international); and estimated tourism spend. This data provides the base for the analysis below of the performance of South Africa's eight metropolitan areas namely Buffalo City (East London), Cape Town, Ekurhuleni, Ethekwini (Durban), Johannesburg. Mangaung (Bloemfontein), Nelson Mandela Bay (Port Elizabeth) and Tshwane (Pretoria).

Table 1: Metropolitan Areas: Growth of Tourism 2001-2012

\begin{tabular}{|c|c|c|c|c|c|c|}
\hline & $\begin{array}{l}\text { Total } \\
\text { Tourism } \\
\text { Trips }\end{array}$ & $\begin{array}{l}\% \\
\text { National } \\
\text { Total }\end{array}$ & $\begin{array}{l}\text { Total } \\
\text { Bednights }\end{array}$ & $\begin{array}{l}\% \\
\text { National } \\
\text { Total }\end{array}$ & $\begin{array}{l}\text { Estimated Total } \\
\text { Tourism Spend } \\
\text { R'000s) }\end{array}$ & $\begin{array}{l}\% \\
\text { National } \\
\text { Total }\end{array}$ \\
\hline 2001 & 9018345 & 39.0 & 65461209 & 41.5 & 33731482 & 52.7 \\
\hline 2006 & 11825467 & 35.6 & 76175235 & 40.2 & 61167164 & 51.3 \\
\hline 2010 & 14026046 & 37.5 & 89580599 & 41.5 & 86943420 & 51.6 \\
\hline 2012 & 13586902 & 39.3 & 90759798 & 41.9 & 88604362 & 53.6 \\
\hline
\end{tabular}

Source: Author calculations from Global Insight data 
Table 2: Metropolitan Areas: Growth of Tourism by source, 2001-2012

\begin{tabular}{lllllllll}
\hline \multicolumn{2}{c}{ No of trips } & \multicolumn{3}{c}{ Share } & \multicolumn{3}{c}{ Bednights } & \multicolumn{3}{c}{ Share } \\
\hline & Dom & Int. & Dom & Int'l & Dom & Int & Dom & Int \\
\hline 2001 & 7157862 & 1862939 & 79.4 & 20.6 & 47046708 & 18426540 & 71.9 & 28.1 \\
2006 & 9112685 & 2717292 & 77.1 & 22.9 & 53039121 & 23142748 & 69.6 & 30.4 \\
2010 & 10407327 & 3618537 & 74.2 & 25.8 & 55454919 & 34116943 & 61.9 & 38.2 \\
2012 & 9432573 & 4155493 & 69.4 & 30.6 & 51470690 & 39293449 & 56.7 & 43.3 \\
\hline
\end{tabular}

Source: Author calculations from Global Insight data

Table 3: Metropolitan Areas: Growth of Tourism by Purpose, 2001-2012

\begin{tabular}{lllllllll}
\hline & Leisure & \% & Business & \% & VFR & \% & Other & \% \\
\hline 2001 & 2446132 & 27.1 & 1282610 & 14.2 & 4669539 & 51.7 & 619882 & 6.9 \\
2006 & 2288524 & 19.4 & 1566471 & 13.2 & 7267676 & 61.5 & 696164 & 5.9 \\
2010 & 3315584 & 23.6 & 2086962 & 14.9 & 7866595 & 56.1 & 759711 & 5.4 \\
2012 & 3318727 & 24.4 & 2438683 & 17.9 & 6937260 & 51.1 & 894093 & 6.6 \\
\hline
\end{tabular}

Source: Author calculations from Global Insight data

Tables 1, 2 and 3 provide a profile of the growth of tourism in the metropolitan areas as a whole. Taken together they confirm the dominance of South Africa's tourism space economy by the country's metropolitan areas (Rogerson, 2014). Several important trends can be observed. Table 1 discloses that between 2001 and 2012 there has been a net growth in indicators of numbers of tourism trips, bednights and estimated visitor spend. The net expansion of trips and bednights was respectively 4.6 million trips and 25.3 million bednights or 50.7 percent and 38.6 percent growth. It is observed that whilst the numbers of tourism trips to metropolitan destinations peak in 2010, the year of South Africa's hosting of the FIFA World Cup, that bednights have continued to grow between 2010 and 2012. Over the period 2001-2012 only marginal change occurs in the share of the metropolitan areas of the national totals; in 2012 South Africa's metropolitan areas account for an estimated 39 percent of trips and nearly 42 percent of bednights. It is observed, however, that the share of total tourism spend which is captured by metropolitan destinations is much higher than the respective share of trips or bednights. It is revealed that between 2001 and 2012 the share of tourism spend accounted for by the eight metropolitan areas rises over 163 percent in this period and the relative share increases from 52.7 to 53.6 percent. This finding points to the higher value of the nature of tourism trips occurring to metropolitan areas as compared to non-metropolitan areas as a whole.

Table 2 breaks down the data of numbers of trips and bednights in terms of source of visitors, whether domestic or international. The category 'international' includes both the lucrative market of longhaul travellers to South Africa, mainly leisure tourists from Europe and the USA, as well as the market of regional African tourists, the largest share of which are involved in cross-border shopping/trading and business tourism rather than leisure tourism (Rogerson \& Visser, 2006). It is shown on Table 2 that as indexed both by trips and bednights that the relative importance of metropolitan areas for international tourists as opposed to domestic tourists is increasing in significance. These figures should also be read in relation to national data for domestic and international trips and bednights which show that in 2012 domestic tourists account for 75 percent of trips and two-thirds of bednights whereas international travellers represent 25 percent of trips and one-third of bednights. It is shown therefore that metropolitan areas as destinations are relatively more important for international travellers and under-represented in terms of their share of total trips/bednights in terms of domestic tourists. 
Table 3 is revealing in terms of unpacking the numbers of trips in terms of purpose of travel. Four categories of tourism are recognised, namely leisure, business, visiting friends and relatives (VFR) and other, which is mainly constituted by religious travel and travel for health purposes. It is shown that in terms of absolute numbers of trips the largest proportion of tourism to metropolitan destinations is represented by VFR travel. This finding is in line with national data that VFR travel in 2012 accounted for 60.8 of all tourism trips. Beyond VFR travel, the next significant purposes of travel are for leisure and business purposes with the category other of only minor significance. Between 2001-2012 it is shown that the largest absolute growth of trips to metropolitan destinations is in VFR travel followed significantly by business rather than leisure trips. This finding points to the critical importance of business tourism as a rising component in the tourism economy of South Africa's leading cities (Rogerson, 2014). In relative terms the share of leisure and business travel in metropolitan destinations is much higher than the national pattern. For example, in 2012 business travel represented 11.9 percent of all national trips but for metropolitan areas the corresponding share is 17.9 percent. In terms of leisure the 2012 national proportion of trips was 19.7 percent whereas for metropolitan destinations it was recorded at 24.4 percent. This shows that for leisure travel in relative terms the metropolitan areas are strongly represented in this form of travel. By contrast in VFR travel and other travel the metropolitan areas as a whole are under-represented as they record a share much lower than the national share which is accounted for by these forms of tourism.

Table 4: Total Tourism Trips by Metropolitan Area 2001-2012

\begin{tabular}{|c|c|c|c|c|c|c|c|c|}
\hline & 2001 & & 2006 & & 2010 & & 2012 & \\
\hline & Trips & $\%$ & Trips & $\%$ & Trips & $\%$ & Trips & $\%$ \\
\hline Buffalo City & 433886 & 4.8 & 582473 & 4.9 & 684591 & 4.9 & 33371 & 3.9 \\
\hline Cape Town & 1667448 & 18.5 & 1796100 & 15.2 & 2085006 & 14.9 & 34 & 13.3 \\
\hline Ekur & 133646 & 12.6 & 1307044 & 11.1 & 1705085 & 12.2 & 18 & 13.5 \\
\hline Ethe & 3 & 17.3 & $2987^{\prime}$ & 25.3 & 295 & 21.1 & 28 & 21.0 \\
\hline Joha & 1922127 & 21.3 & 2350292 & 19.9 & 311 & 22.2 & 191 & 23.7 \\
\hline Man & 461798 & 5.1 & 598796 & 5.1 & 601250 & 4.3 & 504753 & 3.7 \\
\hline Nels & 462816 & 5.1 & 644027 & 5.4 & 762910 & 5.4 & 599460 & 4.4 \\
\hline Tshwane & 1375472 & 15.3 & 1562966 & 13.2 & 2119378 & 15.1 & 2236130 & 16.5 \\
\hline
\end{tabular}

Source: Author calculations from Global Insight data

Table 5: Total Bednights by Metropolitan Area 2001-2012

\begin{tabular}{|c|c|c|c|c|c|c|c|c|}
\hline & 2001 & & 2006 & & 2010 & & 2012 & \\
\hline & Trips & $\%$ & Trips & $\%$ & Trips & $\%$ & Trips & $\%$ \\
\hline Buffalo City & 3444138 & 5.3 & 3974305 & 5.2 & 4714718 & 5.3 & 3761827 & 4.1 \\
\hline Cape Town & 14266365 & 21.8 & 16094449 & 21.1 & 41992 & 20.0 & 562 & 18.5 \\
\hline Ekurhuleni & 7891934 & 12.1 & 8291821 & 10.9 & 9952791 & 11.1 & 11715423 & 12.9 \\
\hline Ethekwini & 10253668 & 15.7 & 15226102 & 20.0 & 17267446 & 19.3 & 17190979 & 18.9 \\
\hline Johannesburg & 13346688 & 20.4 & 15048559 & 19.8 & 18587164 & 20.7 & 5184 & 22.2 \\
\hline Mangaung & 2829155 & 4.3 & 3028667 & 4.0 & 3059532 & 3.4 & 2696920 & 3.0 \\
\hline $\begin{array}{l}\text { Nelson Mandela } \\
\text { Bay }\end{array}$ & 3572897 & 5.5 & 4317155 & 5.7 & 5208060 & 5.8 & 4225475 & 4.7 \\
\hline Tshwane & 9856379 & 15.1 & 10181476 & 13.4 & 12858100 & 14.4 & 14256554 & 15.7 \\
\hline
\end{tabular}

Source: Author calculations from Global Insight data 
Table 6: Tourism Spend by Metropolitan Area 2001-2012 (R1000, Current prices)

\begin{tabular}{lllllllll}
\hline & $\mathbf{2 0 0 1}$ & & $\mathbf{2 0 0 6}$ & & $\mathbf{2 0 1 0}$ & \multicolumn{2}{c}{$\mathbf{2 0 1 2}$} & \\
\hline & $\mathbf{R 1 0 0 0}$ & $\mathbf{\%}$ & $\mathbf{R 1 0 0 0}$ & $\mathbf{\%}$ & $\mathbf{R 1 0 0 0}$ & $\mathbf{\%}$ & $\mathbf{R 1 0 0 0}$ & \% \\
\hline Buffalo City & 1279256 & 3.8 & 2191610 & 3.6 & 3451429 & 4.0 & 2845336 & 3.2 \\
Cape Town & 8523951 & 25.3 & 15853005 & 25.9 & 20374159 & 23.4 & 18343530 & 20.7 \\
Ekurhuleni & 3297894 & 9.8 & 5552113 & 9.1 & 8580960 & 9.9 & 10229769 & 11.5 \\
Ethekwini & 4471559 & 13.3 & 9759994 & 16.0 & 13935618 & 16.0 & 14138234 & 16.0 \\
Johannesburg & 7541804 & 22.4 & 13495189 & 22.1 & 19905267 & 22.9 & 22106367 & 24.9 \\
Mangaung & 1331217 & 3.9 & 2019581 & 3.3 & 2450740 & 2.8 & 2165668 & 2.4 \\
Nelson & 1276486 & 3.8 & 2569675 & 4.2 & 4172988 & 4.8 & 3495454 & 3.9 \\
Mandela Bay & & & & & & & & \\
Tshwane & 6014761 & 17.8 & 9713359 & 15.9 & 14078663 & 16.2 & 15285517 & 17.3 \\
\hline
\end{tabular}

Source: Author calculations from Global Insight data

Tables 4, 5 and 6 show the important theme of the divergent trajectories of the different metropolitan destinations. These three tables unpack the data for tourism trips, bednights and tourism spend for the eight different metropolitan areas. What is evident is the differential performance of these eight urban tourism destinations. Table 4 shows that whereas numbers of tourism trips have expanded in all eight metropolitan areas there is evidenced a differential performance. Most striking in a comparison of 2001 and 2012 data is the strengthening of Johannesburg, Ethekwini, Ekurhuleni and Tshwane and the weaker performance of Cape Town and the two smaller metropolitan areas of Mangaung and Buffalo City. These findings are mirrored again by the analysis of bednights with Johannesburg and Ethekwini recording strong relative growth whereas Cape Town, Mangaung, Buffalo City and Nelson Mandela Bay show the weakest performance. The most significant indicator of tourism performance is estimated tourism spend which is given on Table 6. This shows that in absolute terms tourism spend has grown in all eight metropolitan areas over the period 2001-2012 albeit peak tourism spend is recorded in 2010 in several destinations, including Buffalo City, Cape Town, Mangaung and Nelson Mandela Bay. In these four metropolitan areas a downturn in estimated tourism spend is recorded between 2010 and 2012 as opposed to continued upward growth in Johannesburg, Tshwane, Ekurhuleni and Ethekwini. Some significant changes are noted in terms of patterns of tourism spend. In particular, between 2001 and 2010 Cape Town is the most significant destination for tourism spend but by 2012 Johannesburg emerges as the leading destination for tourism spend. Overall, in relative terms for tourism spend the performance of Cape Town is weakened as compared to Johannesburg, Ethekwini and Ekurhuleni which record significant gains.

Table 7: Domestic Tourism Trips by Metropolitan Area 2001-2012

\begin{tabular}{lllllllll}
\hline & 2001 & \multicolumn{2}{c}{ 2006 } & \multicolumn{2}{c}{ 2010 } & \multicolumn{2}{c}{ 2012 } & \\
\hline & Trips & \% & Trips & \% & Trips & \% & Trips & \% \\
\hline Buffalo City & 377746 & 5.3 & 506040 & 5.6 & 636849 & 6.1 & 483196 & 5.1 \\
Cape Town & 1374528 & 19.2 & 1393189 & 15.3 & 1552293 & 14.9 & 1181112 & 12.5 \\
Ekurhuleni & 908669 & 12.7 & 968774 & 10.6 & 1173837 & 11.3 & 1137146 & 12.1 \\
Ethekwini & 1339913 & 18.7 & 2673386 & 29.3 & 2645107 & 25.4 & 2491481 & 26.4 \\
Johannesburg & 1405928 & 19.6 & 1531740 & 16.8 & 1969571 & 18.9 & 1982474 & 21.0 \\
Mangaung & 362478 & 5.1 & 46111 & 5.1 & 433596 & 4.2 & 285718 & 3.0 \\
Nelson Mandela Bay & 421123 & 5.9 & 588358 & 6.5 & 708746 & 6.8 & 533846 & 5.7 \\
Tshwane & 966359 & 13.5 & 967849 & 10.6 & 1290036 & 12.4 & 1340289 & 14.2 \\
\hline
\end{tabular}

Source: Author calculations from Global Insight data 
Table 8: International Tourism Trips by Metropolitan Area 2001-2012

\begin{tabular}{|c|c|c|c|c|c|c|c|c|}
\hline & 2001 & & 2006 & & 2010 & & 2012 & \\
\hline & Trips & $\%$ & Trips & $\%$ & Trips & $\%$ & Trips & $\%$ \\
\hline Buffalo City & 56140 & 3.0 & 54292 & 2.0 & 47742 & 1.3 & 50175 & 1.2 \\
\hline Cape Town & 292920 & 15.7 & 402911 & 14.8 & 532713 & 14.7 & 627022 & 15.1 \\
\hline Ekurhuleni & 224977 & 12.1 & 338271 & 12.4 & 531248 & 14.7 & 692813 & 16.7 \\
\hline Ethekwini & 222190 & 11.9 & 314321 & 11.6 & 308833 & 8.5 & 368180 & 8.9 \\
\hline Johannesburg & 516199 & 27.7 & 818551 & 30.1 & 1146530 & 31.7 & 1237716 & 29.8 \\
\hline Mangaung & 99320 & 5.3 & 137685 & 5.1 & 167654 & 4.6 & 219036 & 5.3 \\
\hline Nelson Mandela Bay & 41693 & 2.2 & 55668 & 2.0 & 54164 & 1.5 & 65614 & 1.6 \\
\hline Tshwane & 409114 & 22.0 & 595117 & 21.9 & 829342 & 22.9 & 895841 & 21.6 \\
\hline
\end{tabular}

Source: Author calculations from Global Insight data

Table 9 Domestic Tourism Bednights by Metropolitan Area 2001-2012

\begin{tabular}{lllllllll}
\hline & 2001 & \multicolumn{2}{c}{ 2006 } & \multicolumn{2}{c}{ 2010 } & \multicolumn{2}{c}{ 2012 } & \\
\hline & Trips & \% & Trips & \% & Trips & \% & Trips & \% \\
\hline Buffalo City & 2830587 & 6.0 & 3410734 & 6.4 & 4128026 & 7.4 & 3135909 & 6.1 \\
Cape Town & 10247719 & 21.8 & 9814343 & 18.5 & 9181313 & 16.6 & 6808278 & 13.2 \\
Ekurhuleni & 5965658 & 12.7 & 5925644 & 11.2 & 5562390 & 10.0 & 5816428 & 11.3 \\
Ethekwini & 7903763 & 16.8 & 12602922 & 23.8 & 14548886 & 26.2 & 13906728 & 27.0 \\
Johannesburg & 8877633 & 18.9 & 9305058 & 17.5 & 9313495 & 16.8 & 10113889 & 19.6 \\
Mangaung & 1906779 & 4.1 & 2257065 & 4.3 & 2007581 & 3.6 & 1309819 & 2.5 \\
Nelson & 3126697 & 6.6 & 3747082 & 7.1 & 4548237 & 8.2 & 3411142 & 6.6 \\
Mandela Bay & & & & & & & & \\
Tshwane & 6170488 & 13.1 & 5963871 & 11.2 & 6185718 & 11.2 & 6976638 & 13.6 \\
\hline Soun
\end{tabular}

Source: Author calculations from Global Insight data

Table 10 International Tourism Bednights by Metropolitan Area 2001-2012

\begin{tabular}{lllllllll}
\hline & 2001 & & 2006 & & 2010 & \multicolumn{2}{c}{ 2012 } & \\
\hline & Trips & \% & Trips & \% & Trips & \% & Trips & \% \\
\hline Buffalo City & 613551 & 3.3 & 563570 & 2.4 & 586691 & 1.7 & 625918 & 1.6 \\
Cape Town & 4018646 & 21.8 & 6280106 & 27.1 & 8760679 & 25.7 & 9953284 & 25.3 \\
Ekurhuleni & 1926275 & 10.5 & 2366178 & 10.2 & 4390401 & 12.9 & 5898995 & 15.0 \\
Ethekwini & 2349906 & 12.8 & 2623180 & 11.3 & 2718561 & 8.0 & 3284251 & 8.4 \\
Johannesburg & 4469055 & 24.3 & 5743501 & 24.8 & 9273669 & 27.2 & 10031295 & 25.5 \\
Mangaung & 922376 & 5.0 & 721959 & 3.1 & 1051951 & 3.1 & 1387101 & 3.5 \\
Nelson Mandela Bay & 446200 & 2.4 & 570073 & 2.5 & 659823 & 1.9 & 814332 & 2.1 \\
Tshwane & 3685891 & 20.0 & 4217605 & 18.2 & 6672382 & 19.6 & 7279916 & 18.5 \\
\hline
\end{tabular}

Source: Author calculations from Global Insight data

Tables 7 and 8 provide the breakdown for the eight metropolitan areas of tourism trips as differentiated by source of visitor, whether domestic or international. Tables 9 and 10 provide the parallel data for bednights. Taken together these four tables provide further striking evidence of the divergent trajectories taken by South Africa's eight metropolitan areas as tourism destinations. Two critical sets of findings must be observed. First, in relation to domestic tourism is the marked strengthening in relative importance of Ethekwini and Johannesburg as domestic tourism destinations. By contrast is the considerable decline in the significance for domestic tourism relatively of Cape Town. Other destinations showing relative decline for domestic travel between 2001 and 2012 are Buffalo City, Ekurhuleni, Mangaung and Nelson Mandela Bay. Second, in terms of international tourism different 
trajectories are observed. The data for tourism trips reveals the rise of Johannesburg, Ekurhuleni and Tshwane for international tourism; in all cases regional African visitors represent the largest proportion of international travel cohorts in these destinations. It is observed also that in terms of numbers of bednights Cape Town is becoming ever stronger as a magnet for international tourists, albeit in this destination it is mainly long-haul travelers as opposed to regional African visitors. For international tourism, as indexed both by relative share of bednights and trips, Ethekwini experienced a weakening of its former position. Declines are also clearly evident in the performance of the smaller metropolitan areas of Buffalo City, Mangaung and Nelson Mandela Bay for international tourism.

Table 11: Leisure Tourism Trips by Metropolitan Area 2001-2012

\begin{tabular}{lllllllll}
\hline & 2001 & & 2006 & & 2010 & \multicolumn{2}{c}{ 2012 } \\
\hline & Trips & \% & Trips & \% & Trips & \% & Trips & \% \\
\hline Buffalo City & 127753 & 5.2 & 90264 & 3.9 & 113226 & 3.4 & 78909 & 2.4 \\
Cape Town & 658570 & 26.8 & 572591 & 24.9 & 859920 & 25.9 & 780484 & 23.5 \\
Ekurhuleni & 190922 & 7.8 & 157976 & 6.9 & 282176 & 8.5 & 365489 & 11.0 \\
Ethekwini & 333207 & 13.6 & 425711 & 18.5 & 491285 & 14.8 & 464648 & 14.0 \\
Johannesburg & 437488 & 17.9 & 405527 & 17.6 & 680594 & 20.5 & 786974 & 23.7 \\
Mangaung & 158709 & 6.5 & 155726 & 6.8 & 174834 & 5.3 & 176141 & 5.3 \\
Nelson & 105679 & 4.3 & 108320 & 4.7 & 164462 & 5.0 & 125881 & 3.8 \\
Mandela Bay & & & & & & & & \\
Tshwane & 434605 & 17.8 & 382567 & 16.6 & 549656 & 16.6 & 539860 & 16.3 \\
\hline
\end{tabular}

Source: Author calculations from Global Insight data

Table 12 Business Tourism Trips by Metropolitan Area 2001-2012

\begin{tabular}{|c|c|c|c|c|c|c|c|c|}
\hline & 2001 & & 2006 & & 2010 & & 2012 & \\
\hline & Trips & $\%$ & Trips & $\%$ & Trips & $\%$ & Trips & $\%$ \\
\hline Buffalo City & 57934 & 4.5 & 60819 & 3.9 & 60446 & 2.9 & 55890 & 2.3 \\
\hline Cape Town & 193752 & 15.1 & 218868 & 14.0 & 268490 & 12.9 & 247843 & 10.2 \\
\hline Ekurhuleni & 134000 & 10.4 & 150168 & 9.6 & 246007 & 11.8 & 323253 & 13.3 \\
\hline Ethekwini & 175350 & 13.7 & 275720 & 17.6 & 254189 & 12.2 & 264075 & 10.8 \\
\hline Johannesburg & 336800 & 26.3 & 406172 & 25.9 & 639494 & 30.6 & 817696 & 33.5 \\
\hline Mangaung & 64491 & 5.0 & 74589 & 4.8 & 79327 & 3.8 & 73716 & 3.0 \\
\hline Nelson Mandela Bay & 51038 & 4.0 & 69302 & 4.4 & 73777 & 3.5 & 66248 & 2.7 \\
\hline Tshwane & 268965 & 21.0 & 310594 & 19.8 & 465638 & 22.3 & 590070 & 24.2 \\
\hline
\end{tabular}

Source: Author calculations from Global Insight data

Table 13 VFR Tourism Trips by Metropolitan Area 2001-2012

\begin{tabular}{lllllllll}
\hline & 2001 & & 2006 & & 2010 & \multicolumn{2}{c}{ 2012 } & \\
\hline & Trips & \% & Trips & \% & Trips & \% & Trips & \% \\
\hline Buffalo City & 233463 & 5.0 & 415364 & 5.7 & 494628 & 6.3 & 383521 & 5.5 \\
Cape Town & 762205 & 16.3 & 955487 & 13.1 & 904186 & 11.5 & 728800 & 10.5 \\
Ekurhuleni & 711287 & 15.2 & 907322 & 12.5 & 1068339 & 13.6 & 1004336 & 14.5 \\
Ethekwini & 902313 & 19.3 & 2066786 & 28.4 & 2022770 & 25.7 & 1912756 & 27.6 \\
Johannesburg & 969749 & 20.8 & 1360377 & 18.7 & 1575454 & 20.0 & 1339801 & 19.3 \\
Mangaung & 224923 & 4.8 & 350118 & 4.8 & 326966 & 4.2 & 237267 & 3.4 \\
Nelson & 270158 & 5.8 & 427884 & 5.9 & 485790 & 6.2 & 370273 & 5.3 \\
Mandela Bay & & & & & & & & \\
Tshwane & 595966 & 12.8 & 784917 & 10.8 & 987104 & 12.5 & 962587 & 13.9 \\
\hline
\end{tabular}

Source: Author calculations from Global Insight data 
Finally, Tables 11, 12 and 13 provide a detailed picture of total trips as differentiated by purpose of travel for the three major segments of leisure, business and VFR travel. The different paths or trajectories of the eight metropolitan areas are once again in evidence. First, in terms of leisure travel absolute growth has occurred in all metropolitan areas with the exception of Buffalo City where leisure trips between 2001 and 2012 record a net decline. In absolute terms Cape Town is the most significant destination for leisure trips from 2001-2010 but is surpassed by Johannesburg in the period 2010-2012. Tshwane, Ekurhuleni and Ethekwini emerge as the next most significant destinations as indexed by numbers of tourism trips (Table 11).

Table 12 shows that in business tourism Johannesburg, South Africa's commercial capital, and Tshwane, the country's administrative capital, have further strengthened their positions as the leading hubs for business travel. In 2001 these two metropolitan areas accounted for 47.3 of business tourism trips whereas in 2012 this had expanded to 57.7 percent. The growth of business tourism in Johannesburg is evident in the landscape of hotel developments which cluster particularly around the Sandton and Rosebank business nodes (Rogerson, 2014a, 2014b). Ekurhuleni also records an increase in its relative share of business trips such that by 2012 it is the third most significant destination for business travel. By contrast, the two metropolitan destinations showing marked decline in their relative importance for business travel are Ethekwini and Cape Town. A downtown is also evident in the performance of Buffalo City, Mangaung and Nelson Mandela Bay for business travel. The uneven performance of the different metropolitan areas for VFR travel is demonstrated on Table 13. The most striking finding is the strengthening of Ethekwini as a hub for VFR travel. As compared to its poor performance in leisure and business travel Ethekwini experienced a near doubling in VFR trips for the period 2001-2012. In relative terms small gains were shown for Buffalo City and Tshwane in respect of VFR travel. By contrast, the other five metropolitan areas show a relative decline in their importance for VFR travel. The most precipitate decline is for the City of Cape Town which experiences even a net absolute decline in VFR travellers across the period 2001-2012.

\section{Conclusion}

Urban tourism research is of growing importance in the global South. In terms of current scholarship on urban tourism, research on South Africa is the best documented. The existing body of writings is mainly comprised of supply-side investigations of the establishment of new tourism products in the country's cities. In this paper an attempt was made to provide a demand-side analysis of urban tourism across South Africa's eight metropolitan areas.

It is evident that the metropolitan areas as a whole are the leading centres for South Africa's tourism economy and that they have experienced a phase of marked growth during the period 2001-2012. Nevertheless, it is revealed that this growth has been uneven across the eight metropolitan areas. Divergent trajectories of urban tourism development are observed. This can be illustrated by looking at the comparative performance of Cape Town, Johannesburg and Ethekwini. The most striking observations are as follows. Cape Town exhibits relative demise for domestic tourism, business travel and VFR travel and a strengthened role for international travel which in large part accounts for the city's continued strong share of tourism spend. Johannesburg emerges as the metropolitan destination which has experienced the greatest change over the study period. Of note is the city's dominant role for business travel, a rising importance for leisure travel and its modest performance for VFR travel. Growth in Johannesburg is on the basis of both domestic and international travelers, the latter mainly of regional African visitors. For Ethekwini, the period 2001-2012 is denoted by the city's continued strong role as a domestic tourism destination in particular for VFR 
travel, and a generally weak performance as a destination for international tourism. These findings point towards the need for the expansion of local level studies which can unpack at a more fine grained scale the factors which are underpinning these divergent trends and performances among South Africa's metropolitan areas as tourism destinations.

\section{Acknowledgments}

Thanks are due to Wendy Job for preparation of the accompanying figure.

\section{References}

Abrahams, R. (2009) Researching the contribution of foreign tourists to the economy of the Cape Town metropole. Journal of Business and Management Dynamics, 2 (2), pp. 97-111

Arbel, A. \& Pizam, A. (1977) Some determinants of urban hotel location: The tourists' inclinations. Journal of Travel Research, 15, pp. 18-22.

Ashworth, G. \& Page, S. (2011) Urban tourism research: Recent progress and current paradoxes. Tourism Management, 32, pp. 1-15.

Azizi, A. (2011) Investigating the aspects of urban tourism in developing countries (with particular reference to Kohgoliyeh and Boyer Ahmad Province in Iran). Journal of American Science, 7 (5), pp. 892-895.

Bégin, S. (2000) The geography of a tourist business: Hotel distribution and urban development in Xiamen, China. Tourism Geographies, 2, pp. 448-471.

Ben-Dalia, S., Collins-Kreiner, N. \& Churchman, A. (2013) Evaluation of an urban tourism destination. Tourism Geographies, 15, pp. 233-249.

Binns, T \& Nel, E. (2002) Developmental local government in post-apartheid South Africa. Regional Studies, 14, pp. 107-134.

Booyens, I. (2010) Rethinking township tourism: Towards responsible tourism development in South African townships. Development Southern Africa, 27 (2), pp. 273-287.

Burgold, J. \& Rolfes, M. (2013) Of voyeuristic safari tours and responsible tourism with educational value: Observing moral communication in slum and township tourism in Cape Town and Mumbai. Die Erde, 144 (2), pp. 161-174. DOI: 10.12854/erde-144-12

Butler, R., Curran, R. \& O’Gorman, K.D. (2013) Pro-poor tourism in a First World setting: Case study of Glasgow Govan. International Journal of Tourism Research, 15, pp. 443457.

Chege, P. \& Mwisukha, A. (2013) Benefits of slum tourism in Kibera slum in Nairobi, Kenya. International Journal of Arts and Commerce, 2 (4), pp. 94-102.

Chege, P.W. \& Wewere, F.K (2014) Assessment of status, challenges and viability of slum tourism: Case study of Kibera slum in Nairobi, Kenya. Research on Humanities and Social Sciences, 4 (6), pp. 38-48.

Ferreira, S. (2011) South African tourism road to recovery: 2010 FIFA soccer world cup as a vehicle. Tourism Review International, 15 (1/2), pp. 91-106.

Ferreira, S. \& Visser, G. (2007) Creating an African Riviera: Revisiting the impact of the Victoria and Alfred Waterfront development in Cape Town. Urban Forum, 18 (3), pp. 227-246.

Frenzel, F. (2013) Slum tourism in the context of the tourism and poverty (relief) debate. Die Erde, 144, pp. 117-128

Frenzel, F., Koens, K. \& Steinbrink, M. (eds.) (2012) Slum Tourism: Poverty, Power and Ethics. London, Routledge.

Fuller, H. \& Michel, B. (2014) 'Stop being a tourist!': New dynamics of urban tourism in Berlin-Kreuzberg. International Journal of Urban and Regional Research, DOI: 10.1111/1468-2427.12124 
Galdini, R. (2007) Tourism and the city: Opportunity for regeneration. Tourismos: An International Multidisciplinary Journal of Tourism, 2 (2), pp. 95-111.

Hall, C.M. \& Page, S. (2009) Progress in Tourism Management: From the geography of tourism to geographies of tourism - a review. Tourism Management, 30, pp. 3-16.

Henderson, J.C. (2014) Global gulf cities and tourism: a review of AbuDhabi, Doha and Dubai. Tourism Recreation Research, 39 (1), pp. 107-114.

Hong, J (2014) Study on urban tourism development based on experience economy in Shanghai. International Journal of Business Science, 5 (4), pp. 59-63.

Ioannides, D. \& Timothy, D. J. (2010) Tourism in the USA: A spatial and social synthesis. London: Routledge.

Ismail, H. \& Baum, T. (2006) Urban tourism in developing countries: In the case of Melaka (Malacca) City, Malaysia. Anatolia, 17 (2), pp. 211-233.

Kadar, B. (2013) Differences in the spatial patterns of urban tourism in Vienna and Prague. Urbani Izziv, 24 (2), pp. 96-111. DOI: 10.5379/urbani-izziv-en-2013-24-02-002.

Kieti, D.M. \& Magio, K.O. (2013) The ethical and local resident perspectives of slum tourism in Kenya. Advances in Hospitality and Tourism Research, 1 (1), pp. 37-57.

Law, C. M. (1992) Urban tourism and its contribution to economic regeneration. Urban Studies, 29, pp. 599-618.

Law, C.M. (1993) Urban tourism: Attracting visitors to large cities. London, Mansell.

Li, M. \& Bihu, W. (2012) Urban tourism in China. London, Routledge.

Miller, D., Merrilees, B. \& Coghlan, A. (2014) Sustainable urban tourism: Understanding and developing visitor pro-environmental behaviours. Journal of Sustainable Tourism. DOI: 10.1080/09669582.2014.912219

Moswete, N., Thapa, B., Toteng, E.N. \& Mbaiwa, J.E. (2008) Resident involvement and participation in urban tourism development: A comparative study in Maun and Gaborone, Botswana. Urban Forum, 19 (4), 381-394. DOI: 10.1007/s12132-008-9041x

Murillo, J., Vaya, E., Romani, J. \& Surinach, J. (2011) How important to a city are tourists and daytrippers?: The economic impact of tourism on the city of Barcelona. Barcelona, University of Barcelona, Research Institute of Applied Economics.

Nel, E. \& Rogerson, C.M. eds. (2005a) Local economic development in the developing world: The experience of Southern Africa, New Brunswick, NJ, Transaction.

Nel, E. \& Rogerson, C.M. (2005b) Pro-poor local economic development in South Africa's cities: Policy and practice. Africa Insight, 35 (4), pp. 15-20.

Ozturk , H.E. \& Terhorst, P. (2012) Variety of urban tourism trajectories: Antalya, Amsterdam and Liverpool compared. European Planning Studies, 20 (4), pp. 665-683.

Pandy, W. \& Rogerson, C.M. (2012) The economic geography of South Africa's call centre industry. Urban Forum, 23 (1), pp. 23-42.

Pandy, W. \& Rogerson, C.M. (2014) South Africa's call centre industry: The emerging challenges of a growing destination in the global South. Mediterranean Journal of Social Sciences, 5 (8), pp. 208-217.

Reid, N. \& Smith, B.W. (2012) Collaboration in local economic development: The case of Toledo. Urbani Izziv, 23 (Supplement 1), pp. S85-S93. DOI: 10.5379/urbani-izziv-en2012-23-supplement-1-008

Richards, G. (2012) Creativity and tourism: The state of the art. Annals of Tourism Research , 38 (4), pp. 1225-1253.

Rogerson, C.M. (1996) Image enhancement and local economic development in Johannesburg. Urban Forum, 7 (2), pp. 139-158.

Rogerson, C.M. (2000) Local economic development in an era of globalisation: The case of South African cities. Tijdschrift voor Economische en Sociale Geografie, 91, pp. 397-411. 
Rogerson, C.M. (2002a) Tourism-led local economic development: The South African experience. Urban Forum, 14, pp. 53-79.

Rogerson, C.M. (2002b) Urban tourism in the developing world: The case of Johannesburg. Development Southern Africa, 19 (1), pp. 169-189. DOI: 10.1080/03768350220123927

Rogerson, C.M. (2004) The impact of the South African government's SMME programmes: A ten year review. Development Southern Africa, 21, pp. 765-784.

Rogerson, C.M. (2006) Creative industries and urban tourism: South African perspectives. Urban Forum, 17, pp. 149-166.

Rogerson, C.M. (2008a) Consolidating local economic development in South Africa. Urban Forum, 19, pp. 307-328.

Rogerson, C. M. (2008b) Shared growth and urban tourism: Evidence from Soweto. Urban Forum, 19 (4), pp. 395-411.

Rogerson, C.M. (2010) Local economic development in South Africa: Key strategic challenges. Development Southern Africa, 27, pp. 481-495.

Rogerson, C.M. (2011a) Tracking local economic development policy and practice in South Africa, 1994-2009. Urban Forum, 22, pp.149-168.

Rogerson, C.M. (2011b) Urban tourism and regional tourists: Shopping in Johannesburg. Tijdschrift voor Economische en Sociale Geografie, 102, pp. 316-330.

Rogerson, C.M. (2013a) Improving market access opportunities for urban small, medium and micro-enterprises in South Africa. Urbani Izziv, 24 (2), pp. 133-143. DOI: 10.5379/urbani-izziv-en-2013-24-02-005

Rogerson, C.M. (2013b) Urban tourism, economic regeneration and inclusion: Evidence from South Africa. Local Economy,28 (2), pp. 186-200. DOI: 10.1177/026909421246379

Rogerson, C.M. (2014) The uneven geography of tourism in South Africa. African Journal of Hospitality, Tourism and Leisure, 3 (1), 1-15.

Rogerson, C.M. \& Rogerson, J.M. (2010) Local economic development in Africa: Global context and research directions. Development Southern Africa, 27, pp. 465-480.

Rogerson, C.M. \& Rogerson, J.M. (2011) Tourism research within the Southern African Development Community: Production and consumption in academic journals, 2000-2010. Tourism Review International, 15 (1/2), pp. 213-222. DOI: 10.3727/154427211X13139345302487

Rogerson, C.M. \& Rogerson, J.M. (2012) Business development and local economic development in South Africa: Addressing the disconnect. Acta Academica, 44 (2), pp. 4169.

Rogerson, C.M. \& Visser, G. eds. (2004) Tourism and development issues in contemporary South Africa. Pretoria, Africa Institute of South Africa.

Rogerson, C. M. \& Visser, G. (2006) International tourist flows and urban tourism in South Africa. Urban Forum, 17, pp. 199-213.

Rogerson, C.M. \& Visser, G. eds. (2007) Urban tourism in the developing world: The South African experience. New Brunswick, NJ: Transaction Press.

Rogerson, C. M. \& Visser G (2011) Rethinking South African urban tourism research. Tourism Review International, 15 (1/2), pp. 77-90.

Rogerson, J.M. (2012) The changing location of hotels in South Africa's coastal cities. Urban Forum, 23, pp. 73-91.

Rogerson, J.M. (2014a) Hotel location in Africa's world class city: The case of Johannesburg, South Africa. Bulletin of Geography: Socio-Economic Series, 25, pp. 181-196.

Rogerson, J.M. (2014b) Unpacking the growth of hotel chains in Africa: Enterprises and patterns. Mediterranean Journal of Social Sciences, 5 (14), pp. 135-146.

Rolfes, M. (2010) Poverty tourism: Theoretical reflections and empirical findings regarding an extraordinary form of tourism. GeoJournal, 75 (5), pp. 421-442. 
Selby, M. (2012) Geographies of tourism and the city, in Wilson, J. (ed.), The Routledge Handbook of Tourism Geographies, pp. 232-239. London, Routledge,

Shoval, N. Kercher, B. Ng, E. \& Birenboim, A. (2011) Hotel location and tourist activity in cities. Annals of Tourism Research, 38, pp. 1594-1612.

Singh, S. (1992) Urban development and tourism: Case of Lucknow, India. Tourism Recreation Research, 17 (2), pp. 71-78.

Smith, A. \& Pappalepore, I. (2014) Exploring attitudes to edgy tourism destinations: The case of Deptford, London. Journal of Tourism and Cultural Change. DOI: 10.1080/147668252014.896371

Spirou, C. (2011) Urban tourism and urban change: Cities in a global economy. New York: Taylor \& Francis.

Steinbrink, M. (2013) Festifavelisation: mega-events, slums and strategic city-staging - the example of Rio de Janeiro. Die Erde, 144 (2), pp. 129-145. DOI: 10.12854/erde-144-10

Visser, G. (2013) Looking beyond the urban poor in South Africa: The new terra incognita for urban geography? Canadian Journal of African Studies, 47 (1), pp. 75-93. DOI: 10.1080/1080.00083968.2013.770593

Visser, G. (2014) The film industry and South African urban change. Urban Forum, 25 (1), pp. 13-34. DOI: 10.1007/s12132-013-9203-3

Visser, G. \& Hoogendoorn, G. (2011) Current paths in South African tourism research. Tourism Review International, 15 (1/2), pp. 5-20. DOI: $10.3727 / 154427211 X 13139345020093$

Visser, G. \& Rogerson, C.M. (2014) Reflections on 25 years of Urban Forum. Urban Forum, 25 (1), pp. 1-11. DOI: 10.1007/s12132-014-9227-3

Wang, Y., Li, G. \& Bai, X. (2005) A residential survey on urban tourism impacts in Harbin. China Tourism Research, 1, pp. 116-129.

Williams, S (2009) Tourism geography: A new synthesis. Abingdon, Routledge.

$\mathrm{Xu}, \mathrm{H} ., \mathrm{Wu}, \mathrm{Y} \&$ Wall, G. (2012) Tourism real estate development as a policy tool for urban tourism: A case study of Dali and Lijiang, China. Journal of China Tourism Research, 8 (2), pp. 174-193. DOI: 10.1080/19388160.2012.677367. 